\title{
Editorial: Practices, Representations and Meanings of Human Mobility in Archaeology
}

\author{
Maja Gori, Martina Revello Lami \& Alessandro Pintucci
}

Ex Novo Journal of Archaeology

\author{
"Of course we immigrants wanna sing all night long \\ Don't you know the singing salves the troubled soul?" \\ (Gogol Bordello, Immigrant Punk, 2005)
}

Every society experiences movement. As a structural component of human behavior and human mind, movement necessarily influences our ways of thinking, our relationship with people, space, time, and traditions; it modifies how we organize as groups, our perception of things and the way in which we interact with them. For its role in shaping societies, mobility has been at the core of archaeology since its inception as a discipline. Throughout archaeology's history, key topics focusing on the movement of people have included, among others: migration and diffusion; identity; invasion, conquest, and imperial imposition; colonialism; trade and the movement of goods, people, and animals; seafaring and its associated technologies; resource acquiring practices; nomadism. However, especially following the processual turn, scholars tended to minimize the impact of movement on human history placing instead major emphasis on theories about culture and its inherent mutability (e.g. Trigger 1989, Anthony 1990). As a result, despite decades of research into the nature of mobility by anthropologists, sociologists and geographers along with the most recent and sometimes controversial contributions of hard sciences - mainly strontium ( $\mathrm{Sr}$ ) and oxygen $(\mathrm{O})$ isotope analysis, and aDNA analyses (on aDNA see Vander Linden 2016, Furholt 2018 and the controversial connection between cultural and biological identities in

Lazaridis et al. 2017) - much archaeological debate seems still to revolve around two polarizing positions: those using movement as all-in-one explanatory device, and those that downgrade its role as active agent in triggering change.

To break the deadlock between mobilist and immobilist theories, archaeology should adopt mobility as an encompassing and more open concept, as already advocated by neighboring disciplines - chiefly anthropology, cultural studies, geography, sociology, science and technology studies, tourism and transport studies - that have highlighted the great variability of historical and modern types of movements. Even though modern scenarios cannot be transposed onto pre-industrialized periods straightforwardly, likewise their study has allowed us to significantly deepen our understanding of human mobility (see e.g. Hamilakis 2016a, 2017; Gori \& Revello Lami 2018), breaking down 
foggy categories generally used by archaeologists, such as demic diffusion and ethnic groups' migrations into different and heterogonous forms of mobility, which operate within and are determined by their specific social, historical and environmental contexts.

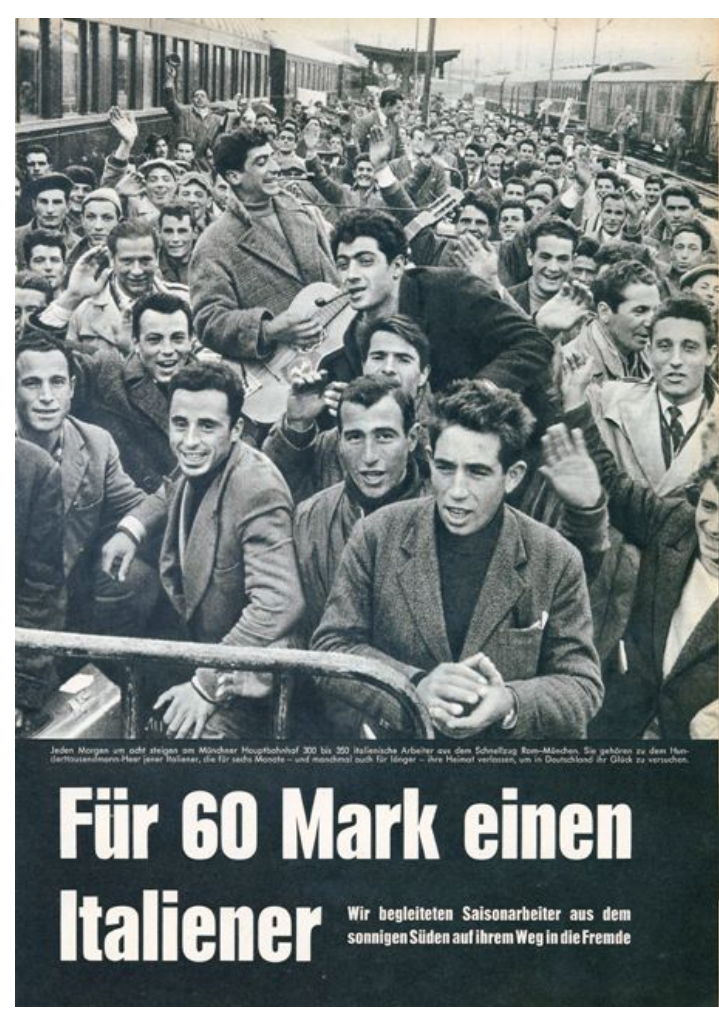

Figure 1. Leaflet published by the Bundesanstalt für Arbeitsvermittlung und Arbeitslosenversicherung in 1963. At that time, hiring workers from Italy costed German companies 60 marks (C) Institut für Zeitungsforschung).

In this sense, human geographers have developed many ways of studying contemporary mobility, focusing on flows and networks of connections, on hybrid geographies of human/nonhuman interactions (Whatmore 2002). As Cresswell (2010: 19, 21) pointed out, mobility "involves a fragile entanglement of movement, representations, and practices." It is the fact of physically getting from one place to another, the different meanings all sorts of movements take on, and, finally, "the experienced and embodied practice of movement". In practice, these components of mobility are not easy to untangle, and different forms of mobility research are likely to explore various facets of any number of these. For instance, positivist analysis has provided a wealth of models for measuring and mapping the material displacement of things and people, yet tracing physical movement is just one aspect of mobility (Hakenbeck 2008). Likewise, social theory based approaches have crafted a multitude of narratives around mobility, alternatively representing it as freedom, as progress, as fundamental to modern Western citizenship, while also treating it as dramatic, as un-ethical, as forced (i.e. Cresswell 2006; within archaeology see for instance Anthony 1992, 1997; Burmeister 2000).

Mobilities are thus socially and culturally encoded and are experienced through practice. Importantly, these three aspects of mobility are political and have implications for the production and reproduction of power relations. In this respect, archaeology holds a privileged position. As opposed to other scholars focusing on movement in modern times, archaeologists may provide a way of comprehending not only the interrelationship between physical movement, representations, and mobile practices, but more significantly how the nature of such interrelationships may vary across wide time spans and contexts. In other words, by providing a view from the past, archaeology may enable us to understand, to use Beudry and Parno words, the

different ways in which mobility has been regulated in different times and places, how this reflects political and social structure, and how differential access to voluntary movement- as well as forced movement 
through human trafficking, persecution, etc. — takes on symbolic import through the narratives a society develops (Beaudry \& Parno 2013: 5).

What place do and should archaeologists have in the debate on migration? How selfreflective have we been about the pasts that we choose to research, and about how we represent them? In the field of Prehistoric archaeology, the occurrence of wide-scale migrations is commonly accepted also on the base of genetic data and radiocarbon dating, even if their definition, nature and modalities keep being a matter of debate. Major examples are discussions on the diffusion of modern humans from Africa, the migration of Neolithic farmers in Europe from the Near Eastern Fertile Crescent at the end of the seventh millennium BCE, the movement of Yamnaya peoples from the Eurasian steppe to Central Europe in the third millennium BCE, or the Bell Beaker phenomenon (on the spread of Bell Beakers see most recently the polemics raised by Olalde et al. 2018). For later periods, on the other hand, the definition and characterization of migratory movements is more controversial, being framed traditionally as invasions by archaeological narratives that are often instrumental in fueling present identities. This is the case, for example, of the period between the third and the sixth century CE, which is commonly defined in Southern European scholarship as the "Age of the Barbarian Invasions" that led the Greco-Roman world to inexorable decay. Significantly, Northern European and overseas scholarship use expressions that are more neutral to indicate the same time span, such as "Migration Period" in English or "Völkerwanderung" in German.

Terminology is but one example of how theories and paradigms in the humanities are influenced by historical, economic and socio-cultural conditions. Modern nation states, established along with the discipline, have profoundly shaped archaeology's representation of migration, which was mostly conceived as the study of the movement of large and homogenous population groups (i.e. nations), whose identity was represented as ethnically (or linguistically) characterized. Within archaeology, the present-day shift of attention from collective to individual agency and the countless facets of migration goes hand in hand with new political scenarios such as the extraordinary migratory flows into Europe, shifting boundaries, alternative forms of citizenship and identity, and the emergence of emotive reactionism.

While African and Middle-Eastern views are generally lacking from the current geopolitical discourse about the contemporary migration to Europe - as well as Central and Southern American do overseas - we should reflect upon how archaeologists can contribute to discuss aspects of present and past migrations. Is it possible to apply the traditional tools of archaeological research to the study of contemporary material and philosophic aspects of mobility (Hamilakis 2016b)? Should we remain loyal only to our professional ethic or should we let a more general ethic prevail here, which entails disclosing the side to which we think to belong (Hamilakis 2007)?

The third issue of Ex Novo gathers a selection of multidisciplinary contributions seeking to evaluate and reassess the concept of mobility and its relationship to materiality in the 
case-studies they are addressing. Papers encompass a wide geographical area and chronological span, ranging from Paleolithic Greece (Elefanti \& Marshall), eighthseventh centuries BCE Southern Italy (Crudo, Raudino), to the Islamic period in the Zagros Mountains region (Rossi). Two papers address controversial aspects related to the Jewish Diaspora respectively during the Hellenistic and Roman Imperial period (Álvarez Folgado) and in seventeenth century Amsterdam (Stolk). Finally, a paper presenting a modern and contemporary case of war material culture turned into popular heritage reflects upon object biography theory (García Sánchez). A book review closes this issue: Paola Di Giuseppantonio comments the volume "Archeosocial. L'archeologia riscrive il web: esperienze, strategie e buone pratiche” edited by A. Falcone \& A. D’Eredità.

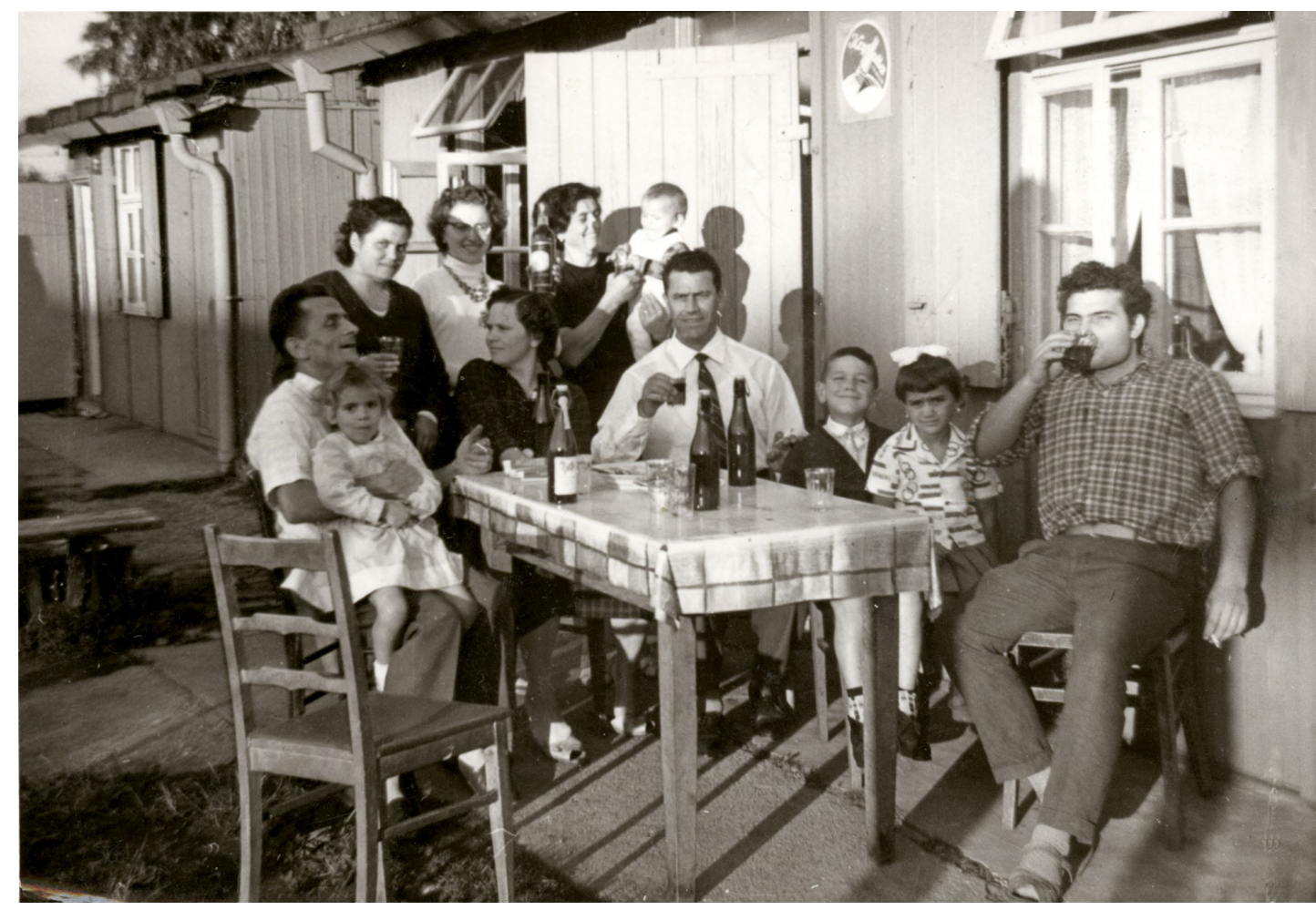

Figure 2. Italian Gastarbeiter portrayed with the family in front of their barracks in Mannheim (1959, City Archive n. AB02833-005, after http://www.daheiminderfremde.de)

\section{Acknowledgments}

We would like to express our gratitude to the authors who contributed to this issue, and to the colleagues who spent time and energies engaging in the double-blind peer review process to which all papers are subjected. Some of them agreed on disclosing their identities and we are glad to thank them individually: Mary Beaudry, Lieve Donnellan, Flavia Frisone Enza Spinapolice, Gianfilippo Terribili and Robert Witcher.

We would also like to express our gratitude to the scientific board members for their help and support.

We owe much also to Claudia D'Angelo, an emergent artist who created especially for this issue the original artwork featured in the cover. 


\section{References}

Anthony, D.W., 1990. Migration in Archaeology: The Baby and the Bathwater. American Anthropologist 92: 895-914.

Anthony, D.W. 1992. The bath refilled: Migration in archaeology again. American Anthropologist 94: 174-176.

Anthony, D.W. 1997. Prehistoric migration as social process, in Chapman, J. \& H. HAMEROW (eds.), Migration and Invasion in Archaeological Exlanation, British Archaeological Reports International Series 664. Oxford: Archaeopress: 21-32.

Beaudry, M. C. \& T. G. Parno (eds.), 2013. Archaeologies of Mobility and Movement. New York: Springer.

Burmeister, S. 2000. Archaeology and migration. Current Anthropology 41(4): 539-567.

CABAnA, G. S. \& J. J. Clark (eds.), 2011. Rethinking Anthropological Perspectives on Migration. Gainesville: University Press of Florida.

Cresswell, T., 2006. On the move. Mobility in the modern Western World. Routledge: London, New York.

Cresswell, T., 2010. Towards a Politics of Mobility. Environment and Planning D: Society and Space 28(1): 17-31.

Furholt, M., 2018. Massive Migrations? The Impact of Recent aDNA Studies on our View of Third Millennium Europe. European Journal of Archaeology 21(2): 159-191.

Gori M. \& M. Revello Lami, 2018. From Lampedusa to Trieste: tracing forced migrations to understand identity patterns, in DRIESSEN J. (ed.), Archaeology of Forced Migrations, AEGIS 15, Louvain: Presses Universitaires de Louvain, 31-53.

HAKENBECK, S., 2008. Migration in archaeology: are we nearly there yet? Archaeological Review from Cambridge 23(2): 9-26.

Hamilakis, Y. 2007. From Ethics to Politics, in Hamilakis, Y. \& P. Duke (eds.), Archaeology and Capitalism, New York: 15-40.

Hamilakis, Y. (ed.), 2016a. Archaeologies of Forced and Undocumented Migration. Journal of Contemporary Archaeology 3(2):

Hamilakis, Y. 2016b. The EU's Future Ruins: Moria Refugee Camp in Lesbos, visited on December 23 2018, https://www.thenation.com/article/the-eus-future-ruins-moriarefugee-camp-in-lesbos.

Hamilakis, Y. (ed.), 2017. The New Nomadic Age: Archaeologies of Forced and Undocumented Migration. Equinox publishing: London.

Lazaridis, I., A. Mittinik, N. Patterson, S. Mallick, N. Rohland, S. Pfrengle, ... G. Stamatoyannopoulos (2017). Genetic origins of the Minoans and Mycenaeans. Nature, $548,214$.

Olalde, I., S. Brace, M. E. Allentoft, I. Armit, K. Kristiansen, T. Booth, D. REICH, 2018. The Beaker phenomenon and the genomic transformation of northwest Europe. Nature 555, 190-196.

VANDER Linden M., 2016. Population history in third-millennium BC Europe: assessing the contribution of genetics. World Archaeology 48(5): 714-728.

Whatmore S., 2002. Hybrid Geographies. Natures Cultures Spaces. Sage: London 
6 M. Gori, M. ReVello LAMI \& A. PintucCI 